\title{
Madame Bovary and Hysteria: A Freudian Perspective
}

\author{
Giuseppe Giordano \\ Department of Mental Health, Azienda Sociosanitaria Ligure 1, Imperia, Italy \\ Email: giugiordano1969@alice.it
}

How to cite this paper: Giordano, G. (2020). Madame Bovary and Hysteria: A Freudian Perspective. Open Journal of Social Sciences, 8, 326-333.

https://doi.org/10.4236/jss.2020.89026

Received: July 15, 2020

Accepted: September 25, 2020

Published: September 28, 2020

Copyright $\odot 2020$ by author(s) and Scientific Research Publishing Inc. This work is licensed under the Creative Commons Attribution International License (CC BY 4.0).

http://creativecommons.org/licenses/by/4.0/

\begin{abstract}
Sigmund Freud's psychoanalytical theories can be used with reference to the analysis of literary works. Reading novels, poems and other compositions through the lens of psychoanalysis gives the opportunity to analyse and evaluate these works in their genesis and functioning. In this article, the main character of Madame Bovary, Emma, is analysed with reference to Freud theories concerning the tripartite structure of the mind (Id, Ego and Superego) along with the Oedipus complex, sexual drives and the analysis of her hysterical personality. The method used for this purpose is the textoanalysis created by a French professor, Jean Bellemin-Noël: several passages from Flaubert's work are highlighted and discussed according to psychoanalytical theories and with a focus on the social role of women in the 19th century.
\end{abstract}

\section{Keywords}

Sigmund Freud, Hysteria, Textoanalysis, Madame Bovary, Gustave Flaubert

\section{Introduction}

Sigmund Freud is generally regarded as the father of psychoanalysis, a branch of psychology that deals with the treatment of mental disorders by exploring aspects of the mind of which an individual is usually unaware. The classical concepts of psychoanalysis, as developed by Freud, have permeated our culture and our knowledge since their medical diffusion. The following terms: unconscious, Id, Ego, Superego, Oedipus complex, sexual urges, death wishes, repression of emotions, transference, defense mechanisms and interpretation of dreams (Fodo $r, 1950)$ are very common and widely accepted by many mental health experts, although there is some skepticism about their scientific basis. However, psychoanalytic theories can be very useful to the analysis of literary works for several reasons, as pointed out by Barry in his theoretical approach to literature (Barry, 
2002). Firstly, it is possible to establish links between the hidden content of a novel or poem and the unconscious and between the explicit content of a text and the conscious. Secondly, the repression of emotions and the revelation of unconscious elements can be linked either to the characters of a composition or to the author himself. Thirdly, theories of sexuality can be associated with representations of emotional distress and of mental dysfunctions in the form of psychological complaints or even manifestations of madness. Fourthly, the Oedipus complex plays a relevant role in influencing gender dynamics and relationships between men and women in social contexts, in example Shakespeare's Hamlet. Finally, the conviction that the analysis of psychological elements is more important for the critical reading of literary works than any other social or historical approach.

\section{Methodology}

The method used for this study is that of textoanalysis developed by a French professor, Jean Bellemin-Noël, which consists in analyzing or interpreting a work of literature through "the unconscious work of the text" (Bellemin-Noël, 2012). In short, this method observes the unconscious functioning of a text which involves the understanding of hidden meanings and relational aspects similarly to what happens during a psychoanalytic treatment. For example, as transference and countertransference manifest themselves in the therapy session between the analysand and the analyst, in the same way emotions and fantasies arise in the relationship between the text and the critic or reader. As a matter of fact, it is the critic who listens to what a text murmurs to his unconscious, leaving aside the author, so that the unknown aspects of the text are revealed. The main objective is therefore the analysis of the character of Emma in the work of Gustave Flaubert, Madame Bovary, with the contribution of Freudian theories, particularly Freud's studies on hysteria and according to the model d interpretation of the textoanalysis. In the end, the analysis concerns the psychology of the character, the different aspects of feminism as well as the problems concerning the social role of women in the 19th century.

\section{Discussion}

In the first chapter of the book, Flaubert's heroine is not yet presented, but her husband is initially described, Charles Bovary. This could mislead the reader but the reason is undoubtedly the greater social importance of men compared to women or of a husband versus his wife. Emma as a female cannot exist without a man or husband. It is interesting to assess to what extent this could have influenced the dissatisfaction of the heroine or that of the female sex since the role of women at that time was to be subjected to men, to have a secondary position and a passive dependence as well as resignation, all aspects that contributed to the manifestation of hysteria (Luz et al., 2019). It is interesting to examine first the character of Charles who is depicted as a clumsy and awkward boy, ridiculed by 
his comrades, his personality traits do not correspond to the social or ideal role of a strong and solid man. He is timid, mediocre and hesitant (“... the dumb ugliness of which has depths of expression, like the face of a imbecile ...") to such a level that he was not able to pronounce his name: "Charbovari". He is humiliated and scorned since he is obliged to write "ridiculus sum" as a form of punishment by his teacher. In this chapter, Flaubert presents also a picture of Charles' family by delineating its dynamics. The father is presented as a man who is not interested in his son: "... his father let him run about barefoot ... go about quite naked like the young of animals". On the other hand, the mother tried in vain to support and educate him but "It is not worth while!", an aspect confirmed by Charles' difficulties to study the medical doctrine and to pass the medical licensing examination. The mother's influence on her son's life was so intense that she was the one who decided that Charles should be married (".. he must have a wife"). Flaubert shows here the situation of the Oedipal triangle which will be widely discussed by Freud a few decades later. In fact, Charles has established a relationship of dependence and submission to his mother, a situation that will affect his character and his future relationships, even the one with Emma. In addition, the father's superficiality and neglect likely affected his personality in a long-lasting way.

If Charles is inept, inexperienced and childish, Emma is unstable, whimsical and seductive according to the first description that Flaubert makes of his heroine in chapter two. The first behaviors described could be considered, according to Freud's theories of sexuality, as the expression of fixations to the oral phase of psychosexual development. In particular, the descriptions given by the author are remarkable: " $\ldots$ as she sewed she pricked her fingers, and quickly put them to her mouth to suck them ...”; “... something of her full lips, which she had the habit to biting ...". Biting own lips or the act of sucking are clearly the manifestation of a search for sensual pleasure linked to the mouth or to the oral cavity similarly to a baby who seeks the pleasure of the mother's breast, the teat or food. These are examples of seductive behavior which are typical of a hysterical and childlike personality like that of Emma. The act of seduction plays an important role for Charles since he is fascinated by this young girl: "Her real beauty was in her eyes. Although brown, they seemed black ... and her glance met one frankly, with a candid boldness". On the other hand, his wife Heloise was anything but charming as the following shows: "... And then his wife was thin ... had long teeth ... bony figure ...". In the first chapters, Flaubert gives us several signs of Emma Bovary's emotional instability such as the repulsion towards intimacy, the intolerance of monotony, the need for very strong sensations, the sudden mood swings that occurred during her last days at the convent and the tendency to daydream especially in association with romantic readings during adolescence which is generally known as a critical period for the development of personality.

The relationship between the two spouses has been problematic from the be- 
ginning. The first signs of conjugal dissatisfaction are described by Flaubert in chapter seven when he uses words like "habit" and "monotony" or even more suggestive is the expression: "her life was as cold ... in every corner of her heart". It is clear that Emma lives a deep psychological distress but the description of her personal situation brings to the conclusion that she suffered from a nervous disease (it was Charles who had made the diagnosis!) or, more precisely, hysterical neurosis. The symptoms of this condition are well presented by the author in part one chapter nine when he describes the following expressions: "Emma was growing difficult and capricious ... one day she drank only pure milk ..."; "She grew pale and suffered from palpitations of the heart .... At times she chatted with feverish rapidity and this over-excitement was suddenly followed by a state of torpor in which she remained without speaking, without moving”; “... contracted a small little cough and completely lost her appetite". In this respect, the similarity of the symptoms presented by Emma with those of the hysterical patients whom Freud had treated is remarkable. For example, the clinical situation of the patient Anna O., a 21-year-old young woman who suffered from several symptoms including nervous cough, mood changes and language impairment (Études sur l'hystérie, 2013), are comparable to those of Mme. Bovary. According to Freud, this disorder is connected to some form of sexual trauma that occurred during the patient's childhood as well as to distorted ideas or false memories of a traumatic sexual experience. In the case of Mme. Bovary, Flaubert does not mention this type of personal life event but he illustrates Emma's suffering for the early loss of her mother, the mood swings, the celerity with which the father gets rid of his daughter and the tendency to daydream, all these are aspects that could provide useful information about a person's unconscious during a psychoanalytic treatment. Furthermore, Freud had postulated that the emotions linked to traumatic experiences, often hidden and repressed in the unconscious, are transformed into somatic symptoms thanks to conversion, a defense mechanism that allows the Ego to better manage unpleasant and terrifying ideas (Luz et al., 2019).

The social condition of women at the time was undoubtedly linked to considerable psychological suffering, but it cannot be said that this was the main cause of the development of hysteria. Freud and other analysts took into consideration several factors to explain this form of neurosis: trauma, personal dissatisfaction, life events and even a disposition to manifest mental problems. In chapter three of the second part of the novel, Flaubert compares Emma's behavior with two other women: the nanny Mme Rollet and Mme Homais, the pharmacist's wife. The former plays the social role of a mother who feeds and takes care of children while the latter ".. she was the best wife in Normandy, gentle as a sheep ...”. Emma, on the contrary, is not able to conform to social demands because she does not love her husband, she does not become attached to her daughter since she would have preferred a son ("A man, at least, is free ... a woman is always hampered"). Moreover, she is bored in the new house in Yvon- 
ville. From a psychoanalytical viewpoint, the Superego, represented by social standards and moral conduct, is struggling with an Ego which is dissatisfied with the present and real situation while the Id, home to unconscious desires, takes the control and leads Emma to commit adultery.

Mme Bovary's life is depicted until its end as a continuous struggle between these three parts of the mental apparatus. The Ego is, somehow, aware of reality as shown by the words uttered by Emma during a conversation with her maid Félicité in chapter V part 2: "But with me, replied Emma, it was after marriage that it began". In addition, the investigation of the Id gives significant information. According to the Freudian perspective (Fossey, 2014), the hysterical woman has unconscious desires of the Other which, in the case of Emma, is represented by her two lovers, Léon and Rodolphe, who are two characters who correspond to the ideal man because they are elegant, dynamic, passionate about culture and also rich, quite the opposite of Charles. The main problem of hysterical personality is that patients are not satisfied only by a romantic relationship but they always desire something else which, in turn, is not enough to satisfy them. In this way, she never manages to achieve a complete and enduring satisfaction because the other does not correspond to her expectations. Flaubert describes this aspect very clearly in chapter VI part 3 when he illustrates Emma's thoughts on her relationship with Leon: "Whence came this insufficiency in life-this instantaneous turning to decay of everything on which she leaned? [...] and the sweetest kisses left upon the lips only an unattainable desire for a greater delight". In the same way, the disdainful words she speaks to Rodolphe in their last meeting are also expression of this dissatisfaction: "And you sit there quietly in your armchair, as if you had not made me suffer enough already! ... and you know it, I might have lived happily ...." and again "And then when I come back to him-to him, rich, happy, free ... he repulses me because it would cost him three thousand francs!"

Hysterical personality is classified today according to the DSM-V Diagnostic and Statistical Manual of Mental Disorders (Skodol, 2018) as Hystrionic personality disorder. This disorder is characterized by excessive expression of emotions, attention seeking behaviour, seductive behavior, romantic interest and feelings of boredom. The DSM describes in detail the clinical criteria that must be fulfilled to make the diagnosis and the symptoms presented by Emma correspond to the clinical elements of this type of mental disorder. Besides, Mme Bovary's disturbance is also associated with depression or melancholy that will lead her to killing herself. The suicide of Flaubert's heroine is presented as an impulsive act when the romantic disappointment and the pressure of debts were so strong and overwhelming that dying was the only way to no longer suffer (Levalet \& Rizet, 2010). The author clearly describes the evolution of this gesture after Emma's meeting with Rodolphe in chapter VIII part 3: "She remained lost in stupor ... Madness was coming upon her ... Now her situation, like an abyss, opened before her ..." and again, when Justin was there as the only spectator, 
“... seized the blue jar ... plunged in her hand, and withdrew it full of a white powder, which she began to eat". The representation of this scene is so intense and moving that the same Flaubert was struck to the point of perceiving the taste of arsenic and actually threw up his dinner. In addition, Emma's suicide could be considered as a failed murder (Rouan et al., 2000) because the Self commits suicide since it considers itself as an object. In this case, the aggressive and sadistic impulses of the Id are directed towards the interior, that is towards the object of love. In other words, Emma ends up the life of an internalized lover instead of reacting aggressively and physically towards Rodolphe.

\section{Conclusion}

In conclusion, Mme Bovary's life is presented by Flaubert as an unsatisfying, wretched and unhappy existence as well as characterized by disappointing and negative romantic relationships. Bovaryism (Delphine, 2009) is the term used by the philosopher Jules de Gaultier to describe the dissatisfaction of Emma, a character who became the symbol of the social condition of women in the 19th century. In this regard, the main aspects of Bovaryism are: constant feelings of boredom associated with lack of happiness, daydreaming and an inclination to lead one's life according to excessive imagination and, a final disappointment which, in turn, causes psychological distress and likely depression. As already mentioned, Emma dislikes her marriage, the monotony of provincial life and the economic constraints. She did like Charles's wife and she does not have a clear and defined social identity. Indeed, this is the condition of women of this epoch: men have a dominant role in family and society; they take all the decisions while women are sadly in a subordinate position with no power or authority. The novel shows several examples of this condition but it is especially from the last chapter that it is possible to comprehend the consequences of Emma's behaviour on people around her. It is impressive that, after her death, Emma leaves on earth the sadness and misery of her feminine and social condition. Charles is forced to pay all the debts of his wife which causes him a serious financial damage; his mother abandons Charles for the indignation and the scandal; the servants of the family will settle elsewhere and the pharmacist, who had been very interested in the life of the Bovary family, ending up by ignoring them completely. It is worth analysing here a dream that Flaubert describes since it gives the reader a clear idea of the life Emma wished for herself. Freud could have used this dream to confirm the diagnosis and to better explore the unconscious of a patient affected by hysterical neurosis. In the dream, the imagination leads Emma to detach from reality, to visualize a lovely life in a virtual world made of splendid landscapes, colors and scents, of a romantic future as shown in chapter XII part 2 (“... a splendid city with domes, and bridges, and ships, forests of citron trees and cathedrals of white marble"). It appears as an idyllic situation which is in opposition to the bitterness of her life. Unfortunately, Emma is awakened by Berthe who was coughing, apparently in an attempt to restore reality: a 
little girl who tries to bring her mother back to her social role. Finally, Flaubert's ability to describe meticulously the most problematic aspects of his heroine's personality is remarkable. The final version of the work took about five years because the author was always looking for the right words, an aspect that somehow corresponds to the time spent by a psychologist, a progressive and thorough exploration of mental functioning.

\section{Conflicts of Interest}

The author declares no conflicts of interest regarding the publication of this paper.

\section{References}

Barry, P. (2002). Beginning Theory: An Introduction to Literary and Cultural Theory. Manchester: Manchester University Press. http://staffnew.uny.ac.id/upload/132299491/pendidikan/beginningtheoryanintroductio ntoliteraryandculturaltheorysecondedition.pdf

Bellemin-Noël, J. (2012). Psychanalyse et Littérature. Paris: PUF. https://doi.org/10.3917/puf.belle.2012.01

Delphine, J. (2009). Le bovarysme, histoire et interprétation d'une pathologie littéraire à l'âge moderne, Flaubert. Résumés de thèses, mis en ligne le 14 février 2009. http://journals.openedition.org/flaubert/411

Études sur l'hystérie S. Freud et J. Breuer (2013). https://www.psychaanalyse.com/pdf/ETUDES_SUR_L_HYSTERIE_FREUD_BREUER 1895.pdf

Flaubert, G. (1857). Madame Bovary: A Study of Provincial Life. New York: Brentano's Publisher.

https://www.stmarys-ca.edu/sites/default/files/attachments/files/Madame_Bovary.pdf

Fodor, N. (1950). Freud: Dictionary of Psychoanalysis. https://www.academia.edu/4093341/Freud_A_Dictionary_of_Psychoanalysis

Fossey, J.-M. (2014). Madame Bovary ou le désir insatisfait de l'hystérique. La clinique lacanienne, 1, 99-110.

https://www.cairn.info/revue-la-clinique-lacanienne-2014-1-page-99.htm

Levalet, N., \& Rizet, C. (2010). Emma Bovary, Flaubert et nous: Un suicide entre mélancolie et hystérie. Psychologie Clinique et Projective, 1, 247-269.

https://www.cairn.info/revue-psychologie-clinique-et-projective-2010-1-page-247.htm https://doi.org/10.3917/pcp.016.0247

Luz, M. C. C. O. et al. (2019). The Structure of Hysteria in Madame Bovary: The (Deviation) of Femininity. European International Journal of Science and Technology, 8, 30-39. https://eijst.org.uk/articles/8.4.4.30-39.pdf

Rouan, G. et al. (2000). Le suicide est-il le meurtre de soi-même? https://hal-amu.archives-ouvertes.fr/hal-01393532/document

Skodol, A. (2018). Trouble de la personnalité histrionique. https://www.msdmanuals.com/fr/professional/troubles-psychiatriques/\%EF\%BB\%BFtr oubles-de-la-personnalité/trouble-de-la-personnalité-histrionique 


\section{Appendix: Definition of Freudian Terms}

(From Fodor N. (1950) “Freud: Dictionary of Psychoanalysis”)

\section{Unconscious}

“... we call' unconscious' any mental process the existence of which we are obliged to assume ... but of which we are not directly aware..."

Id

"It contains everything that is inherited, that is present at birth, that is fixed in the constitutionabove all, therefore, the instincts, which originate in the somatic organization and which find their mental expression in the id in forms unknown to us."

Ego

"We recognize in a man a physical organization which is interpolated between his sensory stimuli and perception of his bodily needs on the one hand, and his motor activity on the other..." Super-Ego

"The Super-Ego holds a special position between the Ego and the Id. It belongs to the Ego, shares its high psychological organization, but stands in an especially intimate connection with the Id."

Oedipus complex

"... so named because its essential substance is found in the Greek myth of King Oedipus ... killed his father and married his mother..."

Repression

"The essence of repression lies simply in the function of rejecting and keeping something out of consciousness." 